UCRL-ID-122903

\title{
Pressure Safety Program Lawrence Livermore National Laboratory
}

Chuck Borzileri

Matt Traini

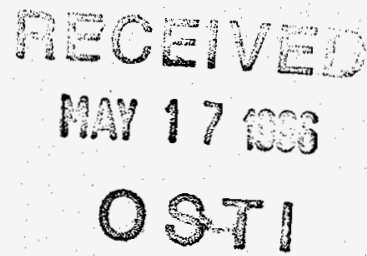

October 1992

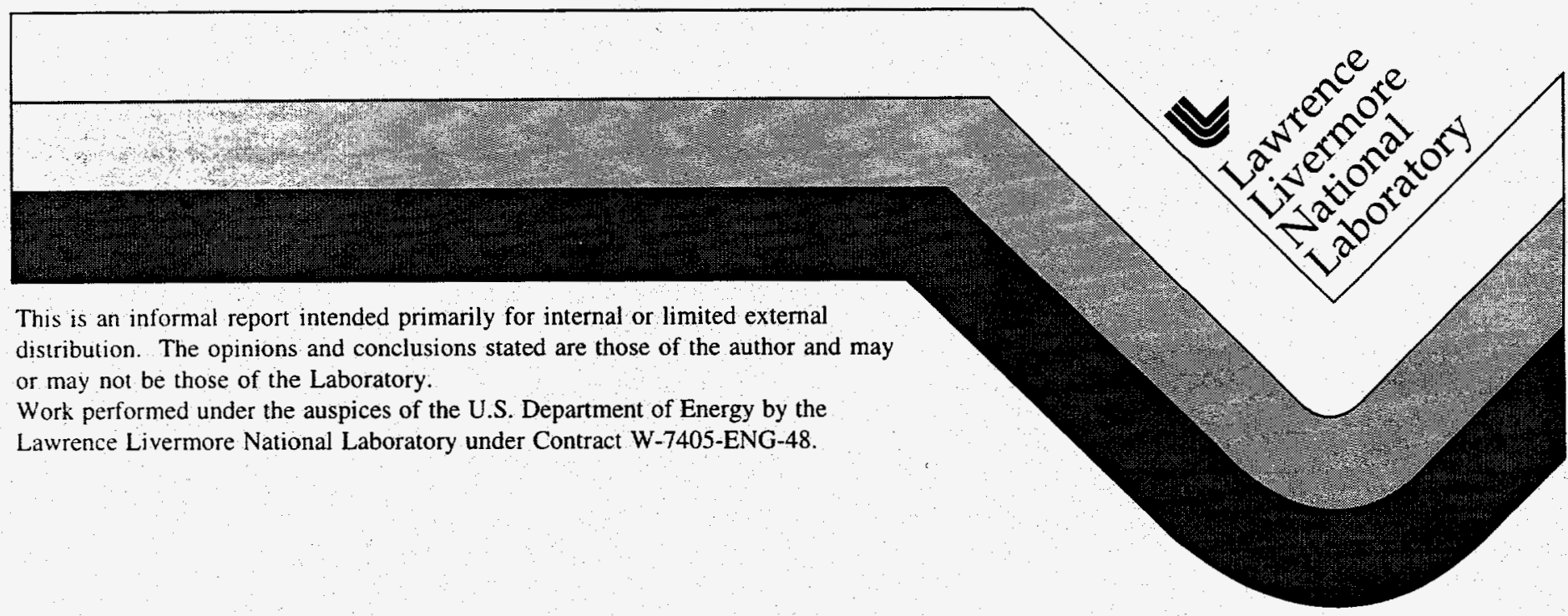




\section{DISCLAIMER}

This document was prepared as an account of work sponsored by an agency of the United States Government. Neither the United Stakes Government nor the University of California nor any of their employees, makes any warranty, express or implied, or assumes any legal liability or responsibility for the accuracy, completeness, or usefulness of any information, apparatus, product, or process disclosed, or represents that its use would not infringe privately owned rights. Reference herein to any specific commercial product, process, or service by trade name, trademark, manufacturer, or otherwise, does not necessarily constitute or imply its endorsement, recommendation, or favoring by the United States Government or the University of California. The views and opinions of authors expressed herein do not necessarily state or reflect those of the United States Government or the University of California, and shall not be used for advertising or product endorsement purposes.

This report has been reproduced directly from the best available copy.

Available to DOE and DOE contractors from the

Office of Scientific and Technical Information

P.O. Box 62, Oak Ridge, TN 37831

Prices available from (615) 576-8401, FTS 626-8401

Available to the public from the

National Technical Information Service

U.S. Department of Commerce

5285 Port Royal Rd.,

Springfield, VA 22161 


\section{DISCLAIMER}

Portions of this document may be illegible in electronic image products. Images are produced from the best available original document. 
PRESSURE SAFETY PROGRAM

\title{
LAWRENCE LIVERMORE NATIONAL
}

\author{
LABORATORY
}

October 1992

Prepared By

Chuck Borzileri, Pressure Safety Manager Matt Traini, Pressure Inspector

\section{Distribution:}

LLNL Pressure Inspectors

LLNL Pressure Consultants

Pressure Safety Files, 3-M.E. Safety Notes

Pressure Safety Files, 5-Pressure Vessel Codes and Standards

M. E. Library L-129

ESD Division 


\section{TABLE OF CONTENTS}

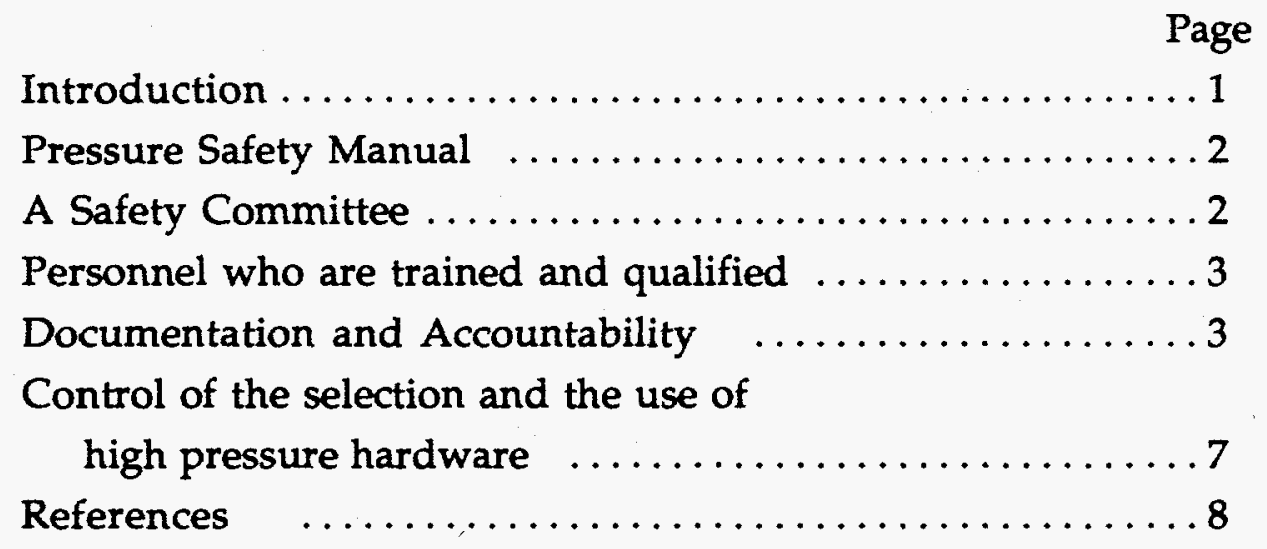

Appendices:

Appendix 1 Hazards Control Course Descriptions

Appendix 2 List of Authorized Individuals for Pressure Work

Appendix 3 Engineering Safety Note (ESN) Guide

Appendix 4 Operational Safety Procedure (OSP) Guidelines

(Chapter 2 of LLNL Health \& Safety Manual)

Appendix 5 LLNL Documentation Guide

Appendix 6 Relief Device Form

Appendix 7 Relief Device Tag

Appendix 8 Sample page from Log Book

Appendix 9 Pressure Test/Inspection Record (Form LL 3586)

Appendix 10 LLNL Pressure Tested Label

Appendix 11 Sample Inspection/Retest Report

Appendix 12 Stored-In-Place Record (Form LL 6278)

Appendix 13 Group Controlled Items - Stock Catalog

Appendix 14 Pressure Safety Codes and Standards 


\section{- INTRODUCTION}

The Lawrence Livermore National Laboratory (LLNL) is a Research and Development facility. Programs include research in: nuclear weapons, energy, environmental, biomedical, and other DOE funded programs. LLNL is managed by the University of California for the Department of Energy.

Many research and development programs require the use of pressurized fluid systems. In the early 1960 's, courses were developed to train personnel to safely work with pressurized systems. These courses served as a foundation for the Pressure Safety Program.

The Pressure Safety Program is administered by the Pressure Safety Manager through the Hazards Control Department, and responsibilities include:

- $\quad$ Pressure Safety course development and training

- Equipment documentation, tracking and inspections/retests

- Formal and informal review of pressure systems

The program uses accepted codes and standards (Page 6) and closely follows the DOE Pressure Safety Guidelines Manual. This manual was developed for DOE by Lawrence Livermore National Laboratory.

The DOE Pressure Safety Guidelines Manual defines five (5) basic elements which constitute this Pressure Safety Program. These elements are:

1. A Pressure Safety Manual

2. A Safety Committee

3. Personnel who are trained and qualified

4. Documentation and accountability for each pressure vessel or system

5. Control of the selection and the use of high pressure hardware 
A detailed description of these elements follows.

1. A Pressure Safety Manual outlines policies, procedures and requirements for pressure vessels and systems to be designed, procured and/or operated by any employee or contractor at LLNL. The DOE Pressure Safety Guidelines Manual fulfills this requirement at LLNL. The manual details and gives examples of :

- $\quad$ Required training

- Theory and calculations

- $\quad$ Equipment specifications and requirements

- Standards for design, testing and operational procedures

- Examples of incidents and accidents

- Exercises and example problems for students

- Inspection requirements

2. The Safety Committee sets and reviews safety policies, addressing unusual problems or occurrences, and provides advice and assistance in pressure safety. The Mechanical Engineering Design Safety Committee provides this service at LLNL. This committee can draw upon the resources of experts and specialists in many areas. 
3. Personnel who are trained and qualified through formal classroom courses, testing and on-the-job experience, design, build and/or operate pressure systems in a safe manner.

- Pressure Safety courses are offered through the Hazards Control Department for all employees or contractors who require them to satisfy job requirements. (Refer to Appendix 1 for course descriptions and outlines.)

- A list of "Authorized Individuals for Pressure Work" is maintained and distributed by the Pressure Safety Manager. (Refer to Appendix 2)

- Requalification for Authorized Individuals is mandatory.

- The Authorized Individuals list is updated annually.

- A data base of all personnel who have attended formal classroom courses is maintained by the training group in the Safety Services Division of the Hazards Control Department.

4. Documentation and accountability for each pressure vessel or system describing the design, pressure ratings, traceability, testing, operation and maintenance requirements where applicable.

- The Engineering Safety Note (ESN) and Operational Safety Procedures (OSP) are the formal documents that are used to describe pressure systems, vessels and their safe operation.

A. The ESN certifies the mechanical integrity of the system and at a minimum it will include the following:

- Description of the system

- $\quad$ Hazards (i.e., stored energy)

- Engineering calculations 
- Test and Retest procedures

- Labeling (identification)

- $\quad$ Associated Procedures

- References

- The required signature authority

See Appendix 3 for Engineering Safety Note Guide

B. The OSP is used to identify related hazards for a system in operation and addresses how these hazards are controlled. The OSP will:

- Describe the activity

- Identify hazards

- Define control measures

- $\quad$ Specify responsible individuals

- $\quad$ Contain the required signature authority

See Appendix 4 for Operational Safety Procedure Guide.

C. Both of these documents are subject to a review process and management sign-off procedures. In order to determine if an ESN and/or an OSP is required, the LLNL Documentation Guide for pressure equipment is used as a reference. Refer to Appendix 5.

- Every vessel or system requiring an Engineering Safety Note must be inspected, tested, documented, and labeled by a qualified LLNL Pressure Inspector. 
- A data base describing the status of all pressure vessels and systems under this program is maintained by the Pressure Safety Manager.

A. In order to trace and account for pressure vessels and systems, the Mechanical Engineering Number Systems (ME\#) is used. For each individual pressure vessel and system, this allows knowledge of:

- Identification

- Location

- $\quad$ Responsible User

- Basis for inspection and testing

Refer to the following appendices for documentation used:

- $\quad$ Appendix 8; Sample page from Log Book.

- $\quad$ Appendix 9; Pressure Tests/Inspection Record (Form LL3586).

- $\quad$ Appendix 10; LLNL Pressure Tested Label. Affixed by pressure Inspectors upon successful completion of documentation and testing.

Original test documentation is stored and maintained in Building 343, Room 1001C, Inspector Reference Library.

- Vessels/systems requiring inspection or re-test are assigned to LLNL Pressure Inspectors.

A. Inspections/re-tests are usually based on a 3/6 year cycle, respectively.

B. Refer to Appendix 11 for sample Inspector/Retest Report from the database.

C. Pressure Test/Inspection Record (Appendix 9) is completed by inspector. This information is used to update the data base. 
D. Equipment not currently being used may be considered "stored in place." The Inspector and Responsible User will sign and complete Form LL6278 (Appendix 12).

- All relief devices are tracked and documented. Users are responsible to have them re-tested or set by an LLNL Pressure Inspector (normally every 3 years).

A. All relief devices, regardless of set pressure, require the completion of an Relief Device Form (RD Form). Each relief device is issued an RD number (similar to a serial number) and related information is stored in a computer data base. Refer to Appendix 6 for Relief Device Form.

B. For proper identification, all relief devices have an attached wire lead sealed tag stating the following information:

- $\quad$ Set Pressure

- Date set

- Expiration date

- $\quad$ RD number

- Inspector

Refer to Appendix 7 for Relief device tag. 
5. Control of the selection and the use of high pressure hardware. This includes quality control requirements for vendors, procurement to applicable specifications, and the issuance to and assembly of high pressure components by certified installers.

- Stores stocked components are purchased through applicable specifications i.e., Engineering Standard References (LLNL), ASME, ANSI, DOT, CGA, etc.

- Items designated as specialty or high pressure components are "Group" controlled (Appendix 13).

- Only Authorized Individuals can obtain Group controlled items (Appendix 2 - "Authorized Individuals for Pressure Work").

- The Purchasing Department alerts Hazards Control or the Pressure Safety Manager to purchases of pressure equipment for review and authorization. 


\section{PRESSURE SAFETY CODES AND STANDARDS}

- $\quad$ Federal OSHA

29 CFR 1910, "General Industry Standards"

29 CFR 1926, "Construction Standard"

- National Fire Protection Association (NFPA)

- American National Standards Institute (ANSI)

- United States Department of Transportation (DOT)

- America Society of Mechanical Engineering (ASME)

- Compressed Gas Association (CGA)

- Local/State Codes

- DOE Order 5000.3A, "Occurrence Reporting"

- DOE Order 5480.4, "Environmental Safety and Health Protection Standard"

- DOE Pressure Safety Guidelines Manual

- Lawrence Livermore National Laboratory Health and Safety Manual

- Design Safety Standards, Mechanical Engineering Department, Lawrence Livermore National Laboratory 


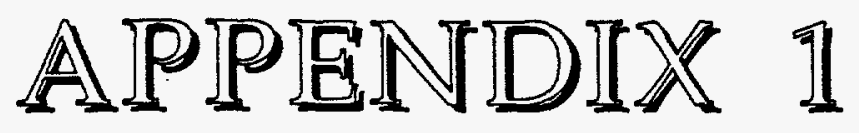

\section{Hazards Control Course Descriptions \& Outlines}




\section{LLNLPRESSURETRAINING REQUIREMENTS}

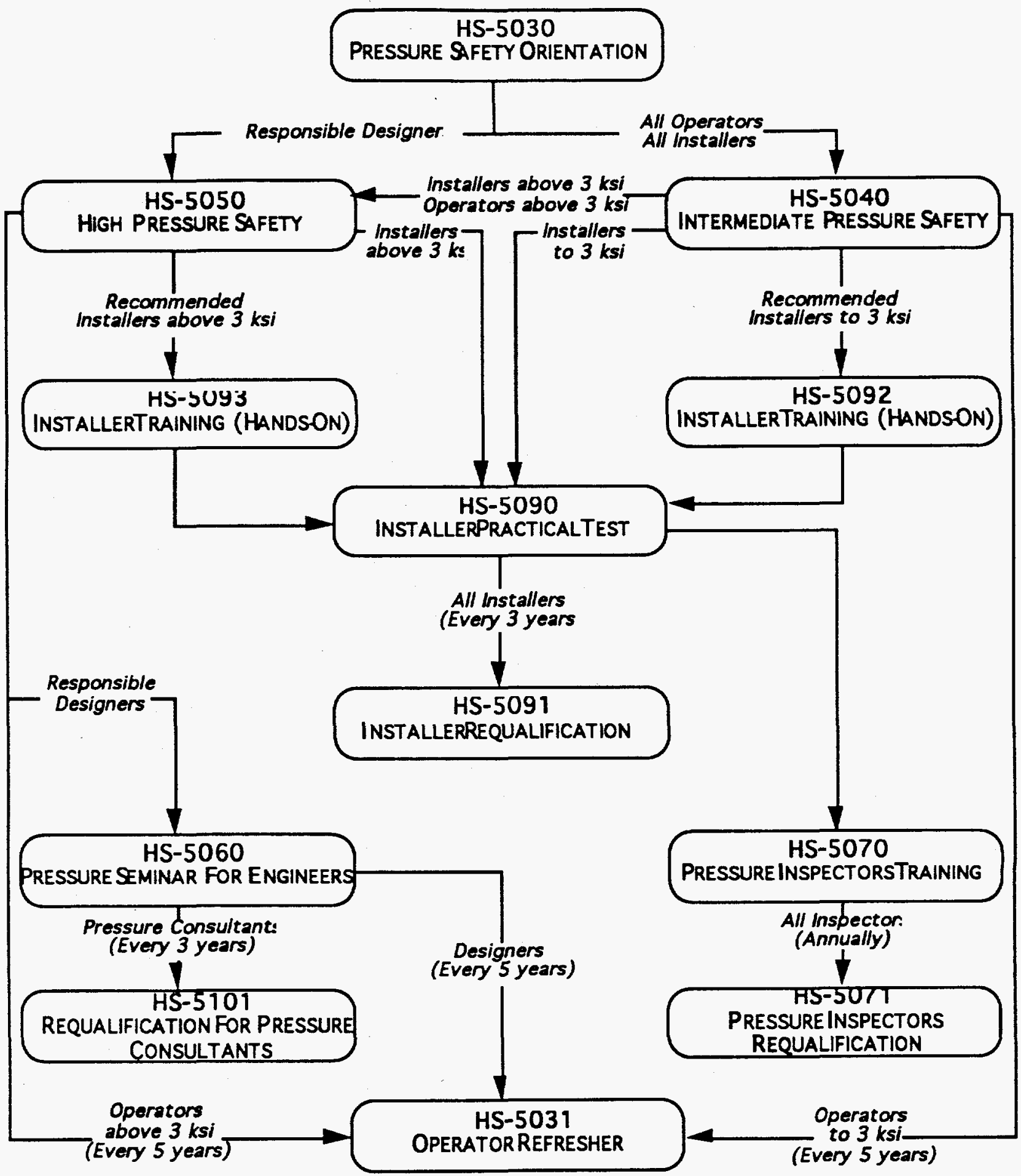

HS: Health \& Safety ksi: 1 ksi $=1,000$ psi

Refer to Health \& Safety Manual Chapter 32, "Pressure" for course description. 
PRESSURE OPERATOR

RESPONSIBLE USER

PRESSURE INSTALLER

PRESSURE INSPECTOR

RESPONSIBLE DESIGNER

PRESSURE CONSULTANT

\section{RESPONSIBILITIES}

An employee designated by an administrative supervisor to operate specific pressure equipment under the direction of the responsible user. Not authorized to install or modify equipment unless employee is also a Pressure Installer.

An employee responsible for the proper operation and maintenance of a system. For systems that require an ESN, ensure inspection and retesting are performed by a Pressure Inspector.

An employee certified to assemble, install and test pressure equipment within a specified range.

An employee trained and qualified to inspect and test pressure equipment. Also expected to provide technical guidance to pressure installers, and Installers-in-training.

An employee responsible for designing a pressure system or vessel. Also responsible for preparing any required Engineering Safety Notes.

An engineer or scientist of demonstrated experience and knowledge who is appointed by the Division Leader and approved by the Department Head. Authorized to approve pressure designs, calculations and requests for pressure equipment. All pressure work done in, or for a department of program is subject to the critical review and approval of this employee. 


\section{LLNL PRESSURE SAFETY TRAINING REQUIREMENTS}

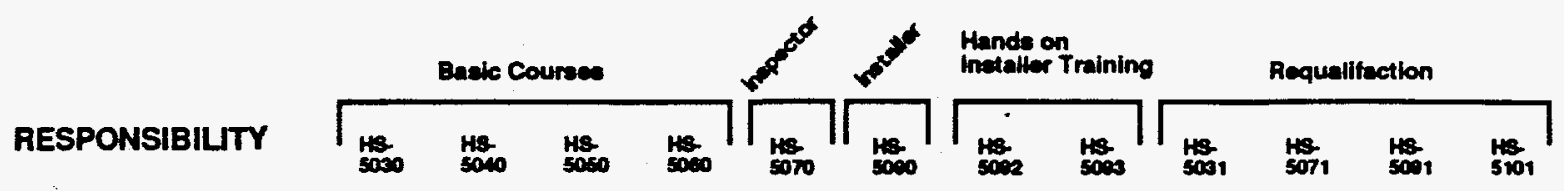

Pressure Operaters / Responsible User

0 - 150 pol gas

0 - 1,500 psi liquid

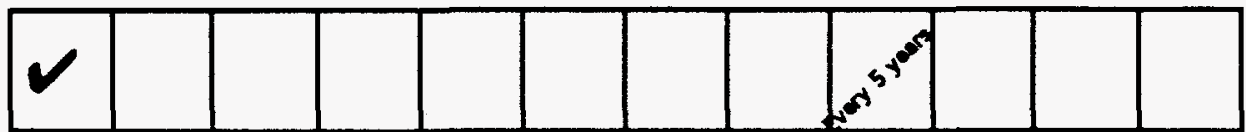

$150-3,000$ psi gas

1,500 - 5,000 poi liquid

above 3,000 psi gas

above 5,000 psi liquid
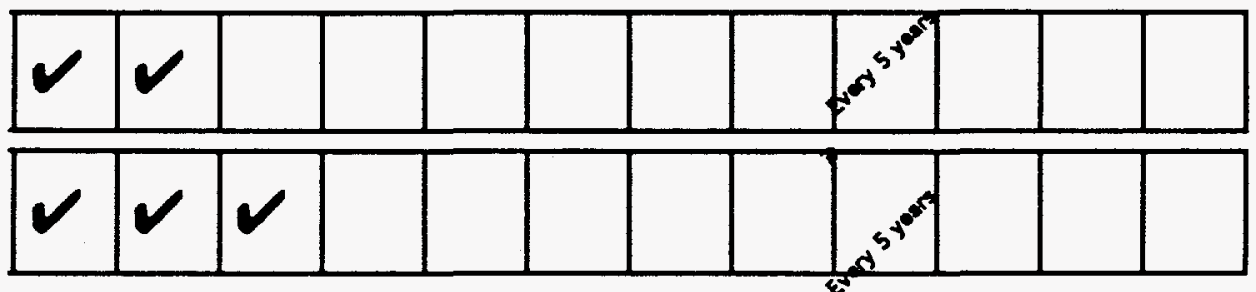

Pressure Installers

$0-3,000$ psi gas

$0-5,000$ psi llquid above 3,000 psl gas above 5,000 psi liquid
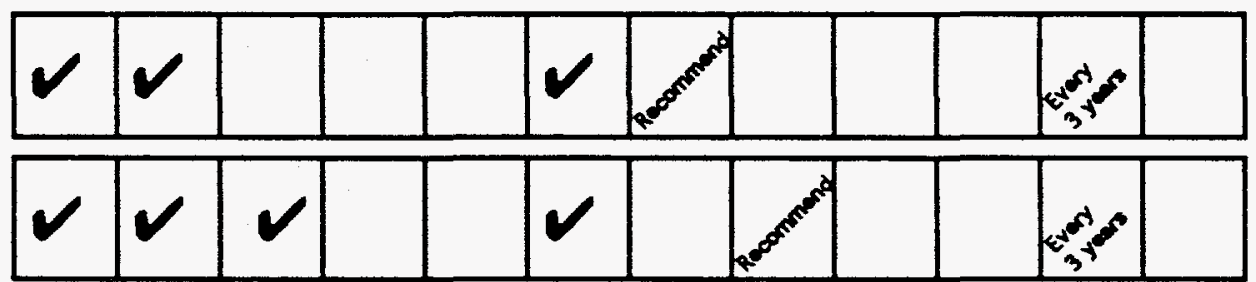

Pressure inspectors 1

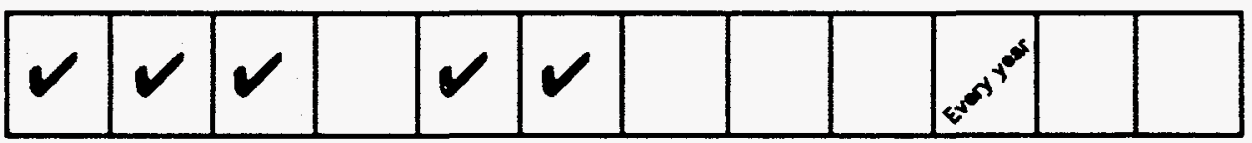

Responsible Designer

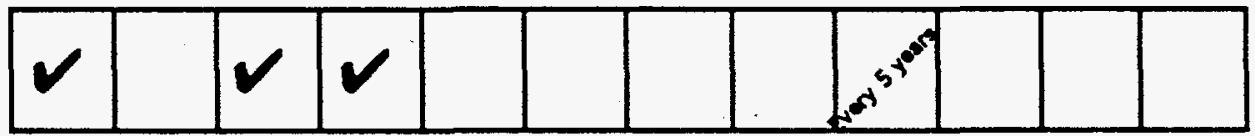

Pressure Consultant $^{2}$

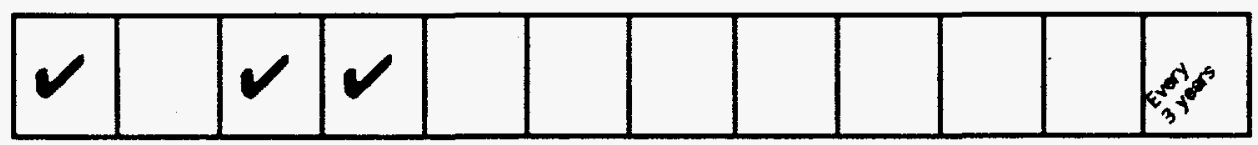

1 Appointed by the Pressure Safety Manager.

2 Appointed by the Division Leader, and Department Head approved.

Reoised 6/92 


\section{HS-5030 (formerly HS-503) Pressure Safety Orientation}

A 4-hour introduction to pressure hazards and the LLNL pressure safety program, this course is recommended for all scientific, technical, and crafts personnel who work with safety-note-exempt pressure systems. It is a prerequisite for all other pressure training. Test given for successful completion. Class notes are provided.

\section{HS-5031 Pressure Safety Requalification}

This course is intended to requalify pressure operators in the low, intermediate, and high pressure ranges. Operators should take this course every five years after successful completion of HS-5030, HS-5040, and HS-5050. Operators of low, intermediate and high pressure equipment who are not Pressure Installers, Inspectors, or Consultants should attend.

\section{HS-5040 (formerly HS-504) Intermediate Pressure Safety}

This 4-hour course is required for all personnel who install or operate gas pressure systems between 150 psi and 3,000 psi or liquid systems between 1500 psi and 5,000 psi. Fluid forces, pressure relationships, equipment and required safety precautions in the intermediate pressure range are covered. After completing this training, personnel may work as pressure operators or installer-in-training in the intermediate pressure range. Pressure Safety training manual and class notes are provided. Test given for successful completion. (HS5030 is a prerequisite for this course.)

\section{HS-5050 (formerly HS-505) High Pressure Safety}

This 4-hour course is required for all personnel who will install or operate gas pressure systems in excess of 3,000 psi or liquid pressure systems in excess of 5,000 psi. Pressure hazards, equipment, and precautions in the high-pressure range are covered. After completing this training, personnel may work as pressure operators or installers-in-training in the high pressure range. Class notes are provided. Test given for successful completion. (HS-5030 and HS-5040 are prerequisites for this course.) 


\section{HS-5060 (formerly HS-506) Pressure Seminar for Engineers}

This 6-hour course is intended to give general guidelines and Laboratory policy and procedures to individuals preparing engineering safety notes. Material from HS-5030 and HS-5050 are required, and additional engineering level materials are covered. Topics include: engineering safety notes and operational procedures; limitations and safety considerations; metallurgy and fracture mechanics; hydrogen safety; and pressure vessel design. This course is required for professionals who wish to become Responsible Users, Responsible Designers, or Pressure Consultants. Problem set assigned for successful completion. (HS-5030 and HS-5050 are prerequisites for this course.)

\section{HS-5070 (formerly HS-507) Pressure Inspectors Training}

Time: As required.

\section{HS-5071 (formerly HS-508) Pressure Inspectors Requalification}

Time: As required.

\section{HS-5090 (formerly HS-511) Pressure Installer Test}

A practical test, given on an individual basis. To become pressure installers, installers-intraining must pass this test. Duration and content varies according to pressure range, usually 2-4 hours. Request from Immediate Supervisor and Division Leader certifying experience to the LLNL Pressure Safety Manager.

\section{HS-5091 (formerly HS-509) Pressure Installers Requalification}

Time: 3-hour updating course every three (3) years.

\section{HS-5092 High Pressure Installers Training (NEW) 0 to 6,000 psi pressure range}

This intensive, 20-hour hands-on training class is designed for mechanical technicians who are intending to become pressure installers. The course provides one-on-one training in various aspects of design and assembly of fluid systems which are to operate at pressures below 6000 psi. 


\section{HS-5093 High Pressure Installers Training (NEW) \\ 6,000 to 60,000 psi pressure range}

This intensive, 40-hour hands-on training class is designed for mechanical technicians who are intending to become high pressure installers. The course provides one-on-one training in various aspects of design and assembly of fluid systems which are to operate at pressures above 6000 psi.

\section{HS-5101 (formerly HS-510) Pressure Consultant Requalification}

Pressure consultants are required to attend this 3-hour updating course every three (3) years to maintain their certification.

For further details, schedules, and costs regarding HS-5092 or HS-5093, contact: Owen Parker, LLNL, (510) 423-1789.

FOR INFORMATION OR QUESTIONS REGARDING PRESSURE SAFETY TRAINING, CONTACT:

Chuck Borzileri

Pressure Safety Manager

Lawrence Livermore National Laboratory

P.O. Box 808 MS L-384

Livermore, CA 94550

(510) 422-6076 


\section{HS-5030 PRESSURE SAFETY ORIENTATION}

\section{SUBJECT OUTLINE}

1. Introduction and Objectives

- Definitions: MOP, MAWP, Safety Factor

- Pressure Ranges vs. Training

2. Compressed Gas Safety

- Color codes, labeling, storage, and transport

- Cylinder relief protection, proper identification

3. Pressure Safety Program

- Basic Elements, concept

4. Pressure Hazards and Accidents

- Causes, severity, and recognition

- Case studies and explanations of Accidents

5. Introduction to Safety - Manifolds and Relief Devices

- Types and uses of regulators

- Cautions regarding relief devices

- Guidelines for gauge selection

6. Cryogenic Safety

- Definitions, awareness

- Emphasis on related hazards, pressure build-up

7. Oxyacetylene Safety

- Use of check valves and flash arrestors

- Guidelines and review of safety

- Optional Film

8. Test 


\section{HS-5040 INTERMEDIATE PRESSURE SAFETY}

\section{SUBIECT OUTLINE}

1. Intermediate Pressure $=$ Definitions and Concepts

- Pressure - Defined

Pressure-force-area

Units of pressure

Types: atmospheric/gage/absolute

Conversion charts

- Temperature - Scales

Conversions

- Liquid - gas comparisons/differences

- Stored energy of fluids

2. Regulators and Intermediate Pressure Equipment

- Difference between pipe \& tube; NPT, NPS

- Piping: ANSI code/pressure ratings

- Temperature considerations

- Valve selection

- Regulators: line, single, two stage

- Fittings: pipe, brass, cajon, flare, compression

- Corrosive gases - handling gas cabinets

- Seals, lubricants and compatibility of materials 
3. Pressure Testing

- Definitions: MAWP, MOP, test pressure

- Test measurements

- Procedures/documentation

- Inspections/retests

- Liquid vs. gases

- In-place testing

- Protection of gauges and reliefs

- Barricade requirements Leak testing - pressure drop bubble tests

leak detectors

4. Test 


\section{HS-5050 HIGH PRESSURE SAFETY}

\section{SUBJECT OUTLINE}

1. High Pressure Theory

- Relationships between Pressure, Temperature, and Volume.

- Ideal gases

- Compressibility, real gases

2. High Pressure Fittings and Equipment

- Fittings - types/ratings/applications

- Pump and Compressors

- Valves - types/cleaning/maintenance

- Vessels/pressure reliefs

- Regulators/gauges/transducers

- Tubing

3. High Pressure System Design

- Pressure system defined

- Ground rules for design and use

- Functions of system components

- Pressure system design problem

4. High Pressure Hydrogen Safety

- Ignition characteristics

- Safety design

- Hardware and equipment

5. Test 


\section{HS-5060 PRESSURE SEMINAR FOR ENGINEERS}

\section{SUBIECT OUTLINE}

1. Engineering Documentation

- Safety notes

- Operational safety procedures

2. High Pressure Amagat Theory

- Ideal gas

- Compressibility, real gases

- Amagat definitions

- Amagat calculations

- Amagat: Definition

Tables and curves

Calculations

3. Pressure Vessel Closures

- Bridgeman

- "O" Ring seals

- Other types of closures

4. Pressure Vessel Design

- Design Definitions: Safety factor

Vessel/system

Manned/remote

- Materials/welding

- Design considerations

- Stress analysis

- SF $\times 3$ vessels

- Hydrogen embrittlement

- Fracture - safe design

- Example Safety Notes 
5. Pressure Testing (repeat from HS-5040)

- Definitions = MAWP, MOP, test pressure

- Test measurements

- Procedures/documentation

- Inspections/retests

- Liquid vs. gases

- In-place testing

- Protection of gauges and reliefs

- Barricade requirements

- Leak testing - Pressure drop

Bubble tests

Leak detectors

6. Illustrative Classroom Problems

7. Test 


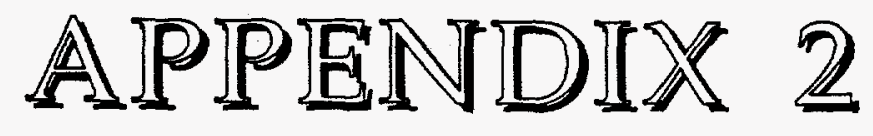

\section{List of Authorized Individuals for Pressure Work}

(updated and available annually through Hazards Control Education Group, L-391, or the Pressure Safety Manager, L-384) 
January 15, 1992

TO: Distribution

FROM: $\quad$ Chuck Borzileri, Pressure Safety Manager

SUBJECT: Personnel Qualifications and Training

Attached please find the most current list of personnel and their last requalification, or the expiration date of their installer or inspector card. This list will be updated each year.

Also attached is a short description of the pressure safety courses by number. The course numbers have been changed to a four digit number; this is to comply with the Laboratory's guidelines on training courses. Please review the course numbers, description, and prerequisites to help you determine which courses are necessary for your particular needs. These courses will be offered in the quarterly LLNL Course Catalog. When the education office of Hazards Control receives an adequate number of sign-ups, the class will be scheduled.

If you have any questions about the courses, or corrections to the list, please contact me at extension 2-6076. Additional copies of this list are available through the Hazards Control Education Department (2-5158, L-391).

Chuck Borzileri

Pressure Safety Manager

CVB:cm

Attachment

Distribution:

Mail List 8

Mail List 15

Mail List 16

Mail List 31

Mail List 35

Mail List 85

File 2-4-2-1

Date File 


\section{Authorized}

\section{Individuals}

for

\section{Pressure}

Work

\section{Revised \\ January 1992}


Chuck Borzileri, Pressure Safety Manager

Bldg. 253, L-384

Extension 2-6076

Responsibilities:

Administration of the LLNL Pressure Safety Program which includes: Pressure safety classes, requalification of Pressure Consultants, Inspectors, and Installers. Record keeping of authorized personnel, pressure vessels, systems, and pressure inspecting, or retesting of all pressure systems.

- Your qualification has expired. Please schedule a requalification course as soon as possible.

** Second Notice: Your qualification has lapsed. If you do not complete a requalification course within the next six months you will be removed from the list of authorized personnel for pressure work.

Some Building Coordinators and those personnel listed in the following pages are authorized to withdraw high pressure equipment from the High Pressure Laboratory in Building 343. IQ BE USED BY QUALIFIED PERSONNEL ONLY.

\section{PRESSURE CONSULTANTS (Re-Qualification every 3 years)}

Chemistry and Materials Science (9812) C.Gatrousis (A.D)

L. T. Summers

L-Code Last Requalification

M. S. Costantino

L-324

$1 / 90$

L-369

$11 / 91$

Earth Sciences Department (9825) L.W. Younker

M. L. Beeman

L-201

$7 / 89$

LLNL Nevada. Nevada Test Site (9761)

R. L. Dury

L-777 $12 / 90$

Mechanical Engineering. Administration (9770) A. K. Chargin (DAD) 


\section{PRESSURE CONSULTANTS (continued)}

Eneroy Systems Engr. Division (9773)

J. M. Bowers

H. G. Patton

R. J. Foley

K. Volkman

J. D. Williams

D. L. Hipple
L-Code

L-471

L-496

$L-482$

$L-460$

L-467

L-492
A. B. Carr

Last Requalification

$11 / 91$

$12 / 90$

$12 / 90$

$11 / 91$

$12 / 90$

$11 / 91$

Aoplied Research Enqineering (9777)

J.N. Doggett

* D. D. Lang

R. E. Priest

L-636

L-273

$12 / 88$

$11 / 91$

Materials Fabrication (9779)

W. R. Ruvalcaba
K. L. Blaedel
$L-341$
$11 / 91$
T. M. Vercelli
L-330
$12 / 90$

Nuclear Explosives Engineering (9772)

A.B. Copeland
R. P. Brown
$L-122$
$11 / 89$
D. C. Holten
$L-122$
$12 / 90$
R. R. Sandberg
L-122
$11 / 91$
F. M. Wilson
L-122
J. Brentjes
L-373
$12 / 90$
$12 / 90$

Nuclear Test Engineering (9771)

J.P. Mahler

E. Russell

L-197

$11 / 91$

Weapons Engineering (9775)

R. E. Clough
J. D. Cervelli
M. W. Wraith
L-125
L-122
$12 / 90$
$12 / 90$

Engineering Sciences Division (9776)

G. S. Boot

\footnotetext{
** J. E. Field

* C. L. Folkers

** F. H. Magness

W. C. Miller
}

L-559

L-362

L-354

L-364 
Engineering Note ENS92-06

Appendix 2 Page 6

\section{PRESSURE CONSULTANTS (continued)}

L-Code Last Requalification
J. T. Merrill
L-354
$11 / 89$
D. I. Chambers
L-341
$12 / 90$
P. B. Mohr
L-333
$12 / 90$
J. E. Hauber
L-129
$11 / 89$
J. W. Gerich
L-354
$11 / 91$
L. L. Dibley
L-362
$11 / 91$

PlantEngineering (9700-9719)

J.W. Cook

** R. L. Frazier

R. R. Kingscott

V. C. Chu

T. A. Boock

R. H. Simonds

P. Sideris

S. Mukherji
L-799

L-395

L-541

L-211

L-654

L-654

L-654
$1 / 88$

$11 / 89$

$12 / 90$

$11 / 91$

$11 / 91$

$12 / 90$

$1 / 92$

Electronics Engineering (9785)

S. R. Trost (Acting DAD)

D. R. Ciarlo

$L-156$

J. A. Folta

L-156

$11 / 91$

$1 / 90$ 


\section{LIST OF PRESSURE INSPECTORS:}

\begin{tabular}{llrrrrrrr} 
& & \multicolumn{1}{c}{ KSI } & KSI & & \multicolumn{2}{c}{ CARD } \\
INSPECTOR & DEPT. & BLDG. & GAS & LIQUID & TEL.NO. & \multicolumn{2}{c}{ MAll EXPIRES } \\
\hline BORZILERI, Charles & ESD & 253 & 60 & 60 & $2-6076$ & L-384 & $1 / 93$ \\
BOWEN, Pete & NEED & 343 & 5 & 5 & $2-9450$ & L-373 & $1 / 93$ \\
CARNAHAN, Roger & NEED & 343 & 80 & 120 & $4-4697$ & L-373 & $1 / 93$ \\
GIRE, Dave & NEED & 343 & 30 & 30 & $4-4694$ & L-373 & $1 / 93$ \\
HAILEY,Gary & PE & 511 & 5 & 5 & $2-9762$ & L-609 & $1 / 93$ \\
HAWE, Jerry & NTS & CP-60 & 30 & 30 & $8-575-3955$ & L-777 & $1 / 93$ \\
IDEKER, Ronald A. & NTS & CP-60 & 60 & 60 & $8-575-3955$ & L-777 & $1 / 93$ \\
KELLY, Brian & NEED & 343 & 30 & 30 & $4-4684$ & L-373 & $1 / 93$ \\
LEVINE, Berry H. & ESED & 231 & 60 & 60 & $3-1962$ & L-344 & $1 / 93$ \\
MARSHALL, Robert F. & NEED & 343 & 30 & 30 & $4-4700$ & L-373 & $1 / 93$ \\
MIHOEVICH, John M. & ESED & 166 & 150 & 150 & $3-8291$ & L-361 & $1 / 93$ \\
NOXON, John M. & NTED & 151 & 5 & 5 & $2-5569$ & L-378 & $1 / 93$ \\
PARKER, Owen D. & NEED & 343 & 150 & 200 & $3-1789$ & L-373 & $1 / 93$ \\
PARKER, Richard & NEED & 261 & 30 & 30 & $2-2632$ & L-385 & $1 / 93$ \\
ROBB, Cal & Y-Div. & 162 & 60 & 150 & $3-9369$ & L-249 & $1 / 93$ \\
ROBERTS, Dave H. & Y-Div. & 1768 & 60 & 60 & $3-7185$ & L-250 & $1 / 93$ \\
RODRIGUEZ, Daniel C. & NEED & 343 & 100 & 150 & $4-4687$ & L-373 & $1 / 93$ \\
ROSS, Timothy & NEED & 343 & 5 & 5 & $2-9596$ & L-373 & $1 / 93$ \\
RUSSELL, Jerry C. & NEED & 343 & 30 & 30 & $3-2752$ & L-373 & $1 / 93$ \\
SARGINSON, John D. & PE & 511 & 5 & 5 & $2-9762$ & L-609 & $1 / 93$ \\
TRAINI, Matt W. & NEED & 343 & 30 & 30 & $2-9596$ & L-373 & $1 / 93$
\end{tabular}

\section{CERTIFICATION COORDINATOR FOR HIGH PRESSURE HARDWARE}

Romero, Emilio

NEED 343

3-2750

L-373

- Pressure Inspectors are qualified Pressure Installers before being appointed Pressure Inspector: the Pressure Safety Manager. 


\section{PRESSURE INSTALLERS}

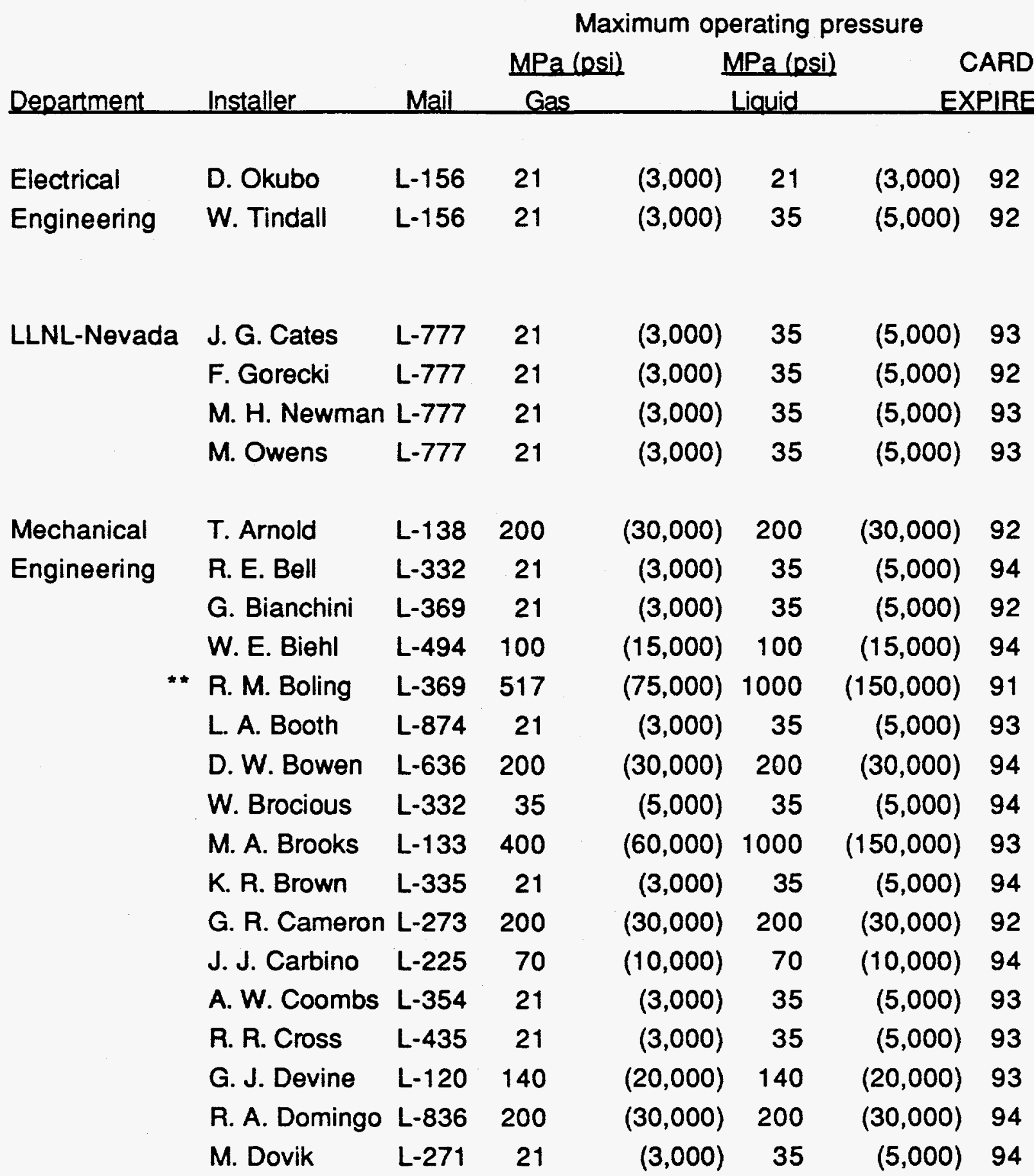


PRESSURE INSTALLERS (continued)

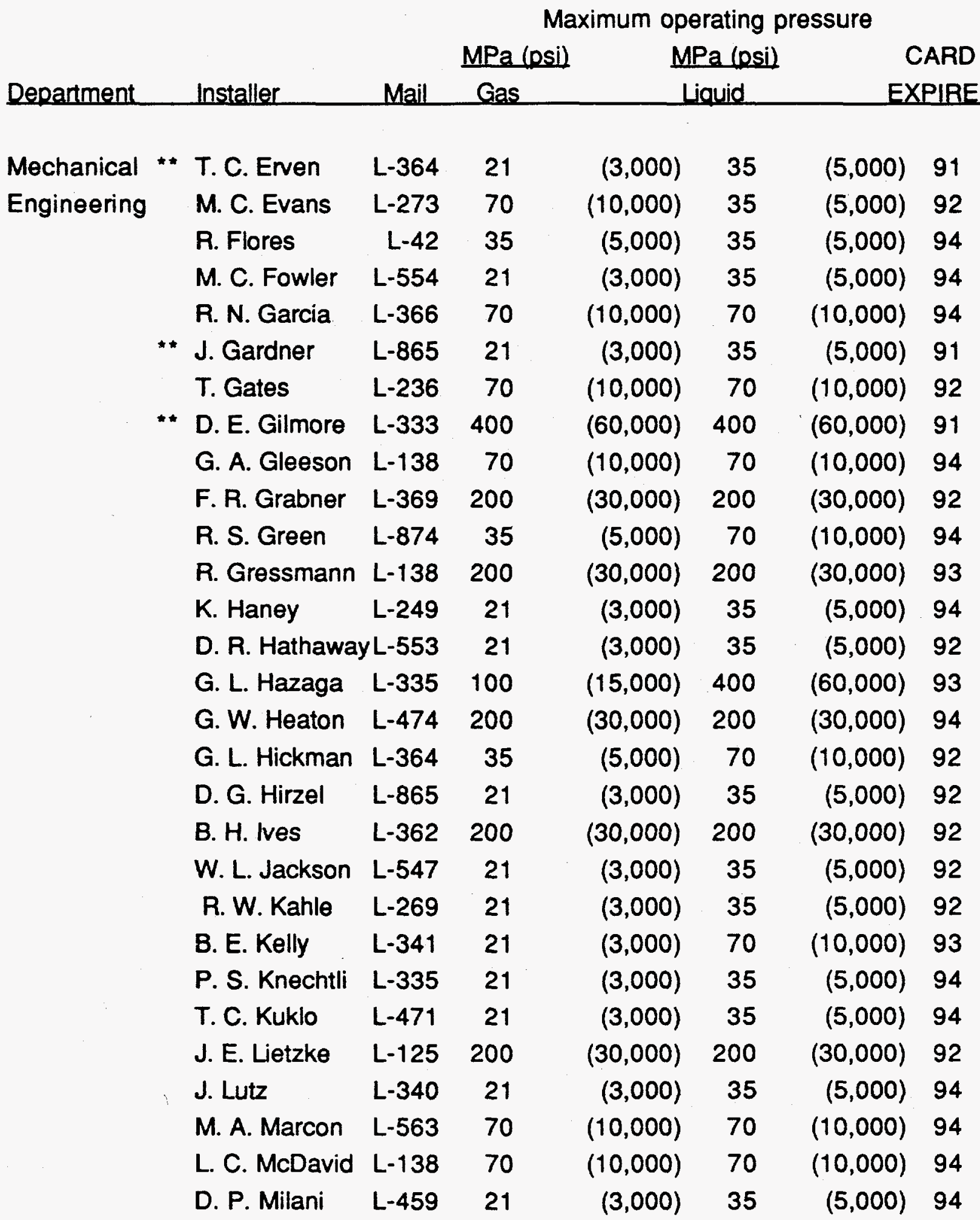




\section{PRESSURE INSTALLERS (continued)}

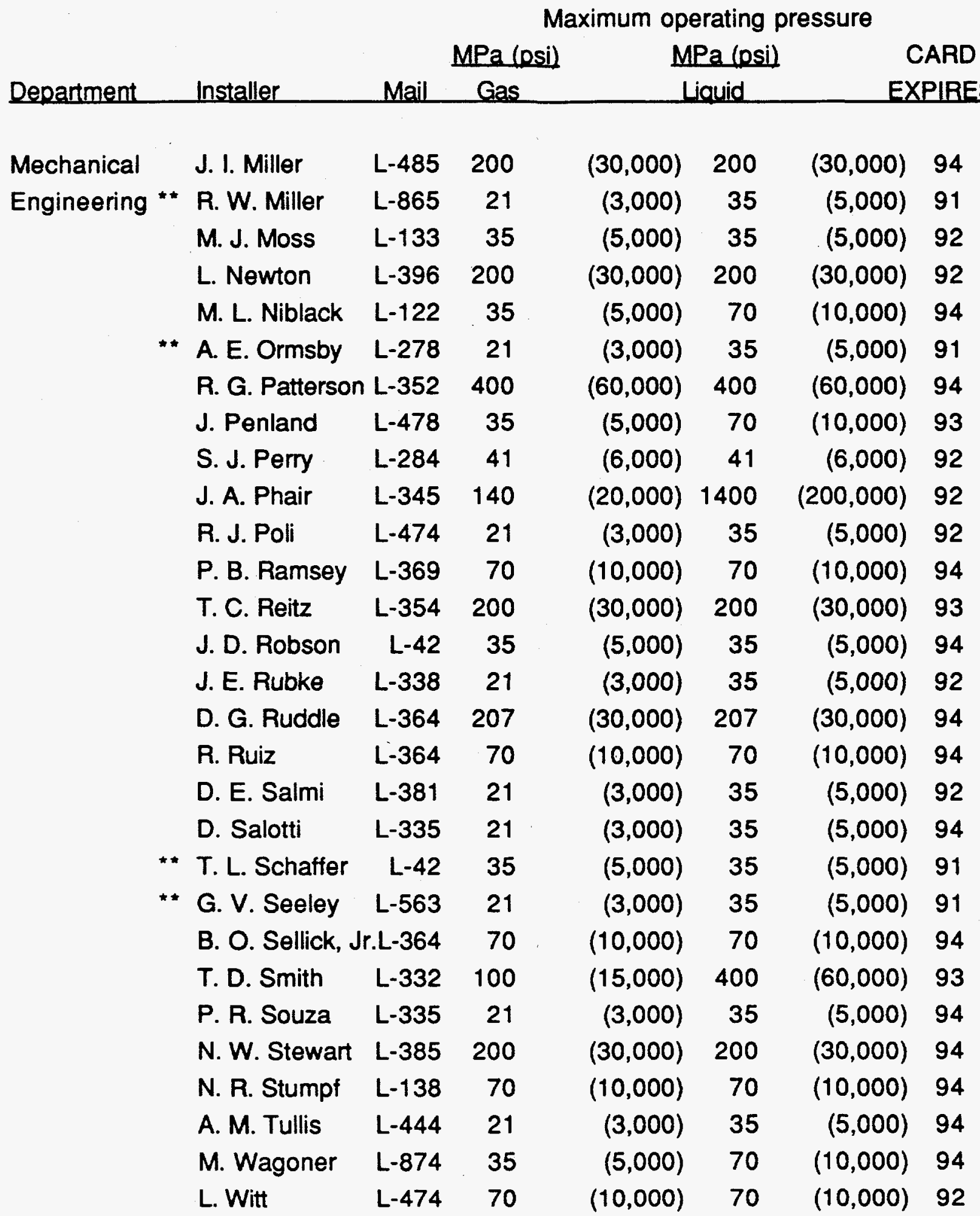




\section{PRESSURE INSTALLERS (continued)}

\begin{tabular}{|c|c|c|c|c|c|c|c|}
\hline \multirow{3}{*}{ Department } & \multirow[b]{3}{*}{ Installer } & \multicolumn{6}{|c|}{ Maximum operating pressure } \\
\hline & & \multirow[b]{2}{*}{ Mail } & \multirow{2}{*}{$\frac{\mathrm{MPa}(0 \mathrm{si})}{\mathrm{Gas}}$} & \multicolumn{2}{|c|}{$\mathrm{MPa}$ (Dsi) } & \multirow{2}{*}{\multicolumn{2}{|c|}{$\begin{array}{c}\text { CARD } \\
\text { EXPIRES }\end{array}$}} \\
\hline & & & & & jquid & & \\
\hline Chemistry \& & T.E. Shell & $L-369$ & 200 & $(30,000)$ & 200 & $(30,000)$ & 94 \\
\hline Mat'I Science & M. Stratman & $L-351$ & 21 & $(3,000)$ & 70 & $(10,000)$ & 92 \\
\hline Plant & J. Adams & L-606 & 21 & $(3,000)$ & 35 & $(5,000)$ & 94 \\
\hline \multirow[t]{7}{*}{ Engineering } & M. McCullough & L-606 & 21 & $(3,000)$ & 35 & $(5,000)$ & 94 \\
\hline & E. A. McGinty & L-606 & 21 & $(3,000)$ & 35 & $(5,000)$ & 91 \\
\hline & G. Olsen & L-606 & 21 & $(3,000)$ & 35 & $(5,000)$ & 94 \\
\hline & R. Reyes & L-606 & 21 & $(3,000)$ & 35 & $(5,000)$ & 94 \\
\hline & G. Riehl & L-606 & 21 & $(3,000)$ & 35 & $(5,000)$ & 94 \\
\hline & M. L. Roberts & L-362 & 21 & $(3,000)$ & 35 & $(5,000)$ & 94 \\
\hline & D. Smith & L-497 & 21 & $(3,000)$ & 35 & $(5,000)$ & 94 \\
\hline P.E. & M. L. Conlin & L-873 & 21 & $(3,000)$ & 35 & $(5,000)$ & 92 \\
\hline \multirow[t]{2}{*}{ (Site 300) } & C. B. Parks & L-873 & 21 & $(3,000)$ & 35 & $(5,000)$ & 92 \\
\hline & W. R. Tondee & L-875 & 21 & $(3,000)$ & 35 & $(5,000)$ & 94 \\
\hline Earth & C. O. Boro & $L-337$ & 1000 & $(150,000)$ & 1000 & $(150,000)$ & 94 \\
\hline Science & W. E. Ralph & L-210 & 1000 & $(150,000)$ & 1000 & $(150,000)$ & 94 \\
\hline
\end{tabular}




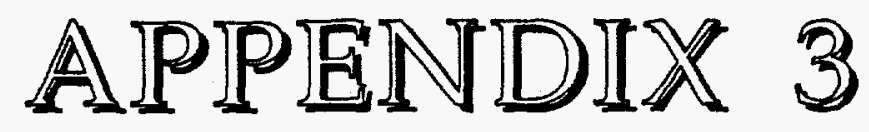

\section{Engineering Safety Note (ESN) Guide}




\title{
Engineering Safety Notes
}

\author{
(ESN's)
}

for

\section{Pressure Vessels and Systems}

\section{(A Guide)}

By: Chuck Borzileri

Pressure Safety Manager

Extension 2-6076

Mail Code L-384

(Revision 2/89) 


\section{Engineering Safety Note}

"A management-approved design document attesting every

practicable precaution has been taken in the design of

equipment to control all significant hazards."

- . - -certifies mechanical integrity- . - - 


\section{Content of Engineering Safety Note}
A. Description
B. Hazards
C. Calculations
D. Pressure Testing
E. Labeling
F. Associated Procedures
G. References
H. Signature Authority
I. Distribution 


\section{A. Description}

What is it?

Physical Size?

What will it be used for?

What is its pressure rating?**

Manned are or remote?

Is it an ASME coded vessel?

Is it a D.O.T. coded vessel?

Are there drawing numbers or sketches you can reference?

Where will it be located?

Building Room

Responsible experimenter or user?

From your description could you find this vessel or system three (3) years from now?

** M.A.W.P. : Relief device setting

M.O.P.: Operating Pressure $10-20 \%$ below M.A.W.P. 


\section{B. Hazards}

What are the hazards:

Stored energy?

Isentropic expansion of a confined gas

$$
\begin{aligned}
& E=\frac{P_{1} V_{1}}{K-1}\left[1-\left(\frac{P_{2}}{P_{1}}\right)^{\frac{K-1}{K}}\right] \\
& \text { Marks Handbook } \\
& \text { 7th Edition (Pages 4-25) }
\end{aligned}
$$

$K=$ value for nitrogen 1.4

$\mathrm{K}=$ value for helium 1.66

$K=$ value for argon 1.67

$\mathrm{K}=$ value for hydrogen 1.41

Manned area, remote use only, radioactive, toxic/corrosive?

If your toxins are in a hood, what happens in a power outage? 


\title{
B. Hazards (continued)
}

What are you going to do to eliminate or lessen the hazards, i.e.:

\author{
hood \\ barricades \\ protective clothing \\ special operating procedures?
}




\section{Calculations:}

For commercial components:

- All components rated at or above M.A.W.P., therefore, no calculations are required.

- Reference manufacturer's ratings, stores catalog ratings.

- List of materials or part numbers.

For vessels/structures:

Include calculations on:

- Weld shear stress

- Tensile stress on bolts, plates

- End closures

- Hoop stress

- Thread shear

- Safety factor

- Remote operation only - calculations on the barricading or shielding used. 


\section{Pressure Testing:}

All pressure testing requires a test procedure. Use this section to write the test procedure.

Specify: test sequence, test pressure, test fluid, hold time, acceptable leak rate.

\section{$\underline{\text { Retest }}$}

You may also want to include the retest procedure. It may be different than the original procedure. You may want to change the frequency of inspection or retest. 


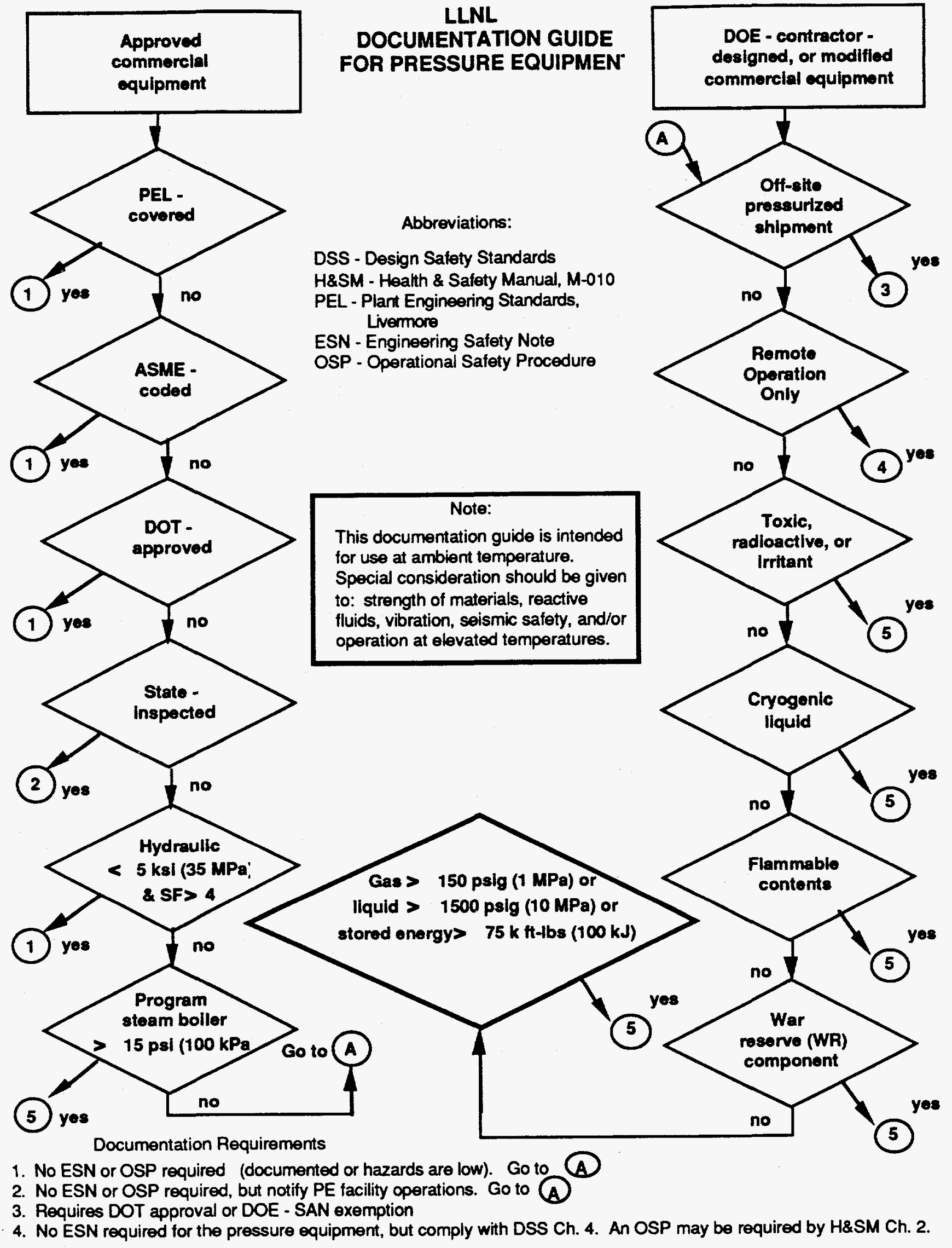




\section{Volume / Pressure limits for a Vessel Containing 100 kJoules of Stored Energy}

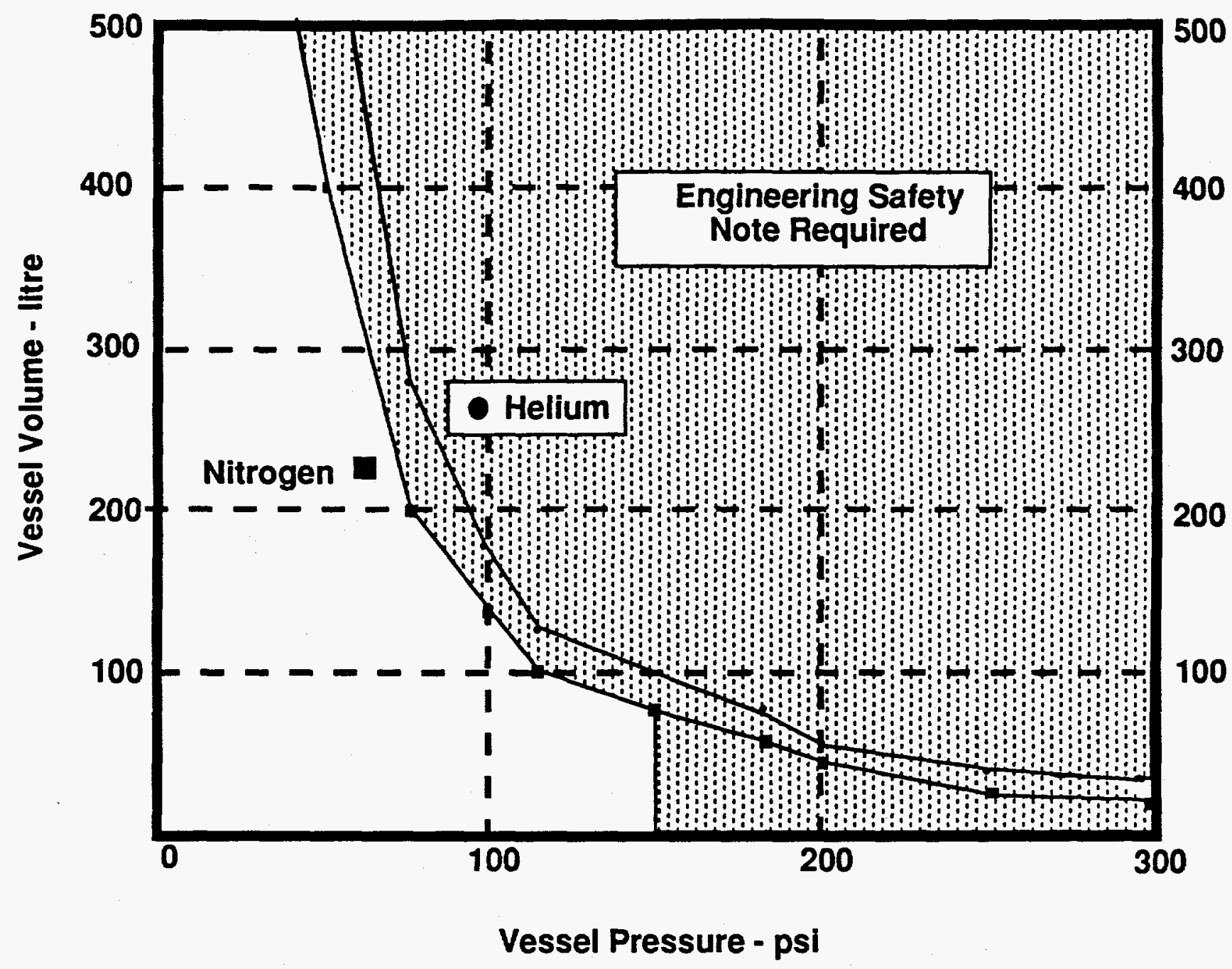




\section{E. Labeling}

\section{LLNL PREssuRe tested} FOR MANNED AREA

A SSY.

SAFETY NOTE

M.A.W.P.

PSIG

FLUID

TEMP.

TO

${ }^{\circ} \mathbf{F}$

REMARKS

TEST NO.

EXPIRATION DATE

BY

$$
\begin{aligned}
& \text { FOR } \\
& \text { REM OTE OPERATION } \\
& \text { ONLY }
\end{aligned}
$$

Remote Operation Label (sllver on red). 


\section{F. Associated Procedures}

Building Procedure (FSP 231 - - )

Operating Procedure (OSP 231 - - )

Special Instructions (referenced) 


\section{G. References:}

Examples:

1. Marks Handbook

7th edition, (Pgs. 4-25)

2. Mechanics of Materials

Miller and Doeringfeld,

Chapter 16

3. M. E. Safety Note ESN 78-954

L. L. Dibley

4. Health and Safety Manual

Supplement 32.03, Pg. 13

5. Formulas For Stress and Strain Roaok, 3rd Ed. 


\section{H. Signature Authority}

Prepared by:

Responsible Designer

Reviewed by:

Pressure Consultant

Approved by:

Division Leader

Approved by:

Deputy Associate Director*

*Brittle materials or S.F. of less than 3 


\section{Distribution}

Recommended Distribution:

Applicable management/supervisors

Pressure Consultant

Industrial Safety Representative

Pressure Safety Representative

Responsible Designer

Central Library/Files

(others concerned including Building Coordinator) 
APIENDIX 4

Operational Safety Procedure (OSP) Guidelines (Chapter 2 of the LLNL Health \& Safety Manual) 


\section{Preparation Guide for Operational Safety Procedures}

This appendix provides guidance for writing an OSP. An OSP assigns responsibility for safe operations, describes the work to be done, identifies the hazards and environmental concerns, and specifies the controls that must be applied to the operation. In addition, and as applicable, the OSP should describe maintenance and quality assurance of safety-related systems and equipment. The ES\&H team for your area can provide guidance and assistance in preparing and processing OSPs.

OSPs and their supplements shall follow the format and address the content in the manner provided in this guide, with modifications only as necessary or appropriate for the particular operation to be described. Editorial instructions are enclosed in brackets ([ ... ]). 


\section{TITLE OF OPERATION}

\subsection{Reason For Issue}

\subsection{Work To Be Done And Location Of The Activity}

\subsection{Responsibilities}

3.1 is responsible for the safety of this operation and for assuring that all work is performed in conformance with this OSP, the FSP, and applicable sections in the Health \& Safety Manual and Environmental Protection Handbook. In the absence of (the responsible individual), shall assume these responsibilities.

3.2 Any changes in operations that improve or do not significantly affect safety and environmental controls may be approved by the authorizing individual for this OSP and the ES\&H Team Leader. The responsible individual will ensure that this action is documented in a memorandum. Any changes in operations that increase the hazard level, introduce additional hazards, or decrease safety shall not be made until a revision of or supplement to this OSP has been reviewed and approved consistent with the review and approval process for the original OSP.

3.3 Before starting operation, the responsible individual shall verify and document that the operating personnel have read and understand the OSP and applicable sections of the FSP.

\subsection{Hazards Analysis}

\section{1}

\subsection{Controls}

The controls specified below will reduce risk to employees and the environment to acceptable levels. 


\subsection{Environmental Concerns and Controls}

\section{1}

\subsection{Training}

7.1 All authorized operators shall have completed the following safety courses:

$$
\text { 7.1.1 [\#] [name] (retraining is required every years) }
$$

7.2 [If required, use the following] All personnel (LLNL and contract) who generate or handle hazardous waste shall attend the following Environmental Protection Department courses within six months of being newly hired and annually thereafter.

7.2.1 EP-0006 Hazardous Waste Handling Practices

7.2.2 EP-0056 Waste Certification

7.3 The responsible individual shall ensure that all required training, including on-thejob training if applicable, is complete and documented.

\subsection{Maintenance}

\subsection{Quality Assurance}

\subsection{Emergency Response Procedures}

\subsection{References}

\subsection{Review and Approval}


This OSP was reviewed by:

Responsible Individual

Group/Section Leader

Facility Manager/Supervisor

ES\&H Team Leader

Hazards Control Department Head

Div. Leader/Dept. head for Facility

Div. Ldr/Dept. Head/Program Mgr. for Program

Materials Management (if appropriate)

Supervisor of Matrixed personnel

Peer Review Board (if explosives are used)

Assurance Manager 
Environmental Protection Department Head

Concurrence:

Facility AD (if different from Program AD)

This OSP approved by:

AD for Program conducting experiment

Controlled Distribution:

Appendices 
APPENDIX 5

\section{LLNL Documentation Guide}




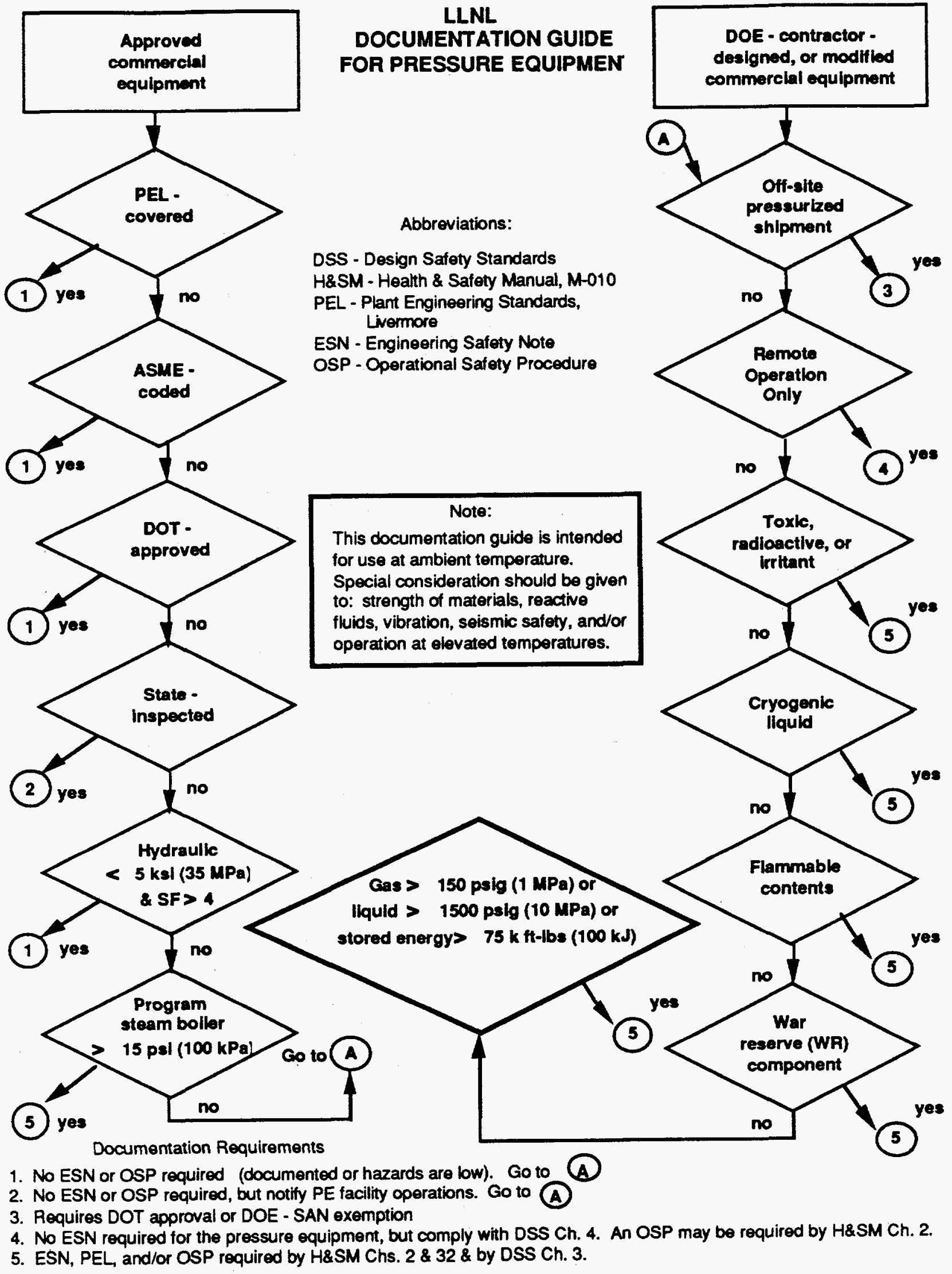




\section{APPENDIX 6}

Relief Device Request Form 


\section{RELIEF DEVICE (RD) REQUEST FORM \\ HIGH PRESSURE LABORATORY}

BIdg. 343 Ext. 2-9569
R.D. \#s

\section{Date:}

Acct. No.:

R.D. Location:

System Fluid:

System MAWP:

Requested Pressure Setting:

System

Responsible User:

Applicable Eng. Safety Note:

INERT GAS

WATER

OTHER

Test Fluid:

\section{:}

Spring Actuated

Mfg.

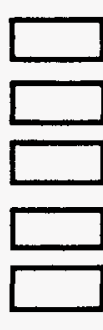

$\square$
$\square$
$\square$
$\square$
$\square$

CIRCLE SEAL

NUPRO CPA

NUPRO R3A

VICTOR

OTHER
Style

VENTED

NON-VENTED
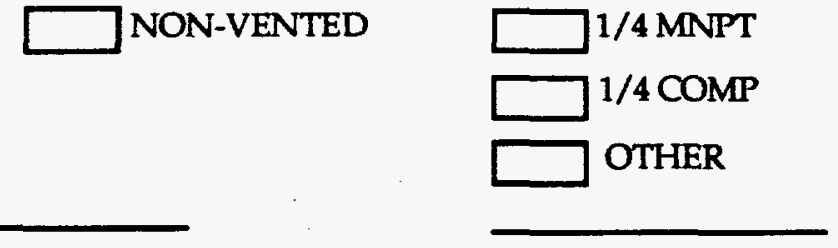

Port Configuration

IN

QUT

1/4 FNPT

$1 / 4$ COMP

OTHER

\section{Nominal Setting **}

* Note: For most devices the operator will be able to set the pressure to within plus or minus two or three percent of the desired value However, because of the limitations in accuracy and uncertainties of the equipment used, LLNL cannot guarantee this setting to be better than $\pm 5 \%$. If the manufacturer's tolerance is larger than this, the rated accuracy will prevail.

\section{Rupture Disks}

Mfg.

\section{AUTOCLAVE 1/4 ANGLE}

OTHER

\section{Actual Rating ***}

$\pm$ $\%$

Note: Commercially available rupture disks are supplied by the manufacturer with a pressure rating of $+6 \%$ to $-3 \%$ of nominal catalog value. This rated value, at which the disk should burst, is guaranteed by the manufacturer to be within $\pm 5 \%$.

Setting performed by: Date:

I, the requester, realize that I am responsible for pointing out to the HPL Supervisor or the Pressure Inspector any known or expected hazardous conditions or materials, such as toxic or radioactive components, associated with this relief device or system. Furthermore I understand that relief devices shall be reset every three years, and that this is to be initiated by the responsible user.

Signature of Requester: Approved by: 
Engineering Note ENS92-06 Appendix 7 Page 1

APPENDIX 7

Relief Device Tag 
FRONT

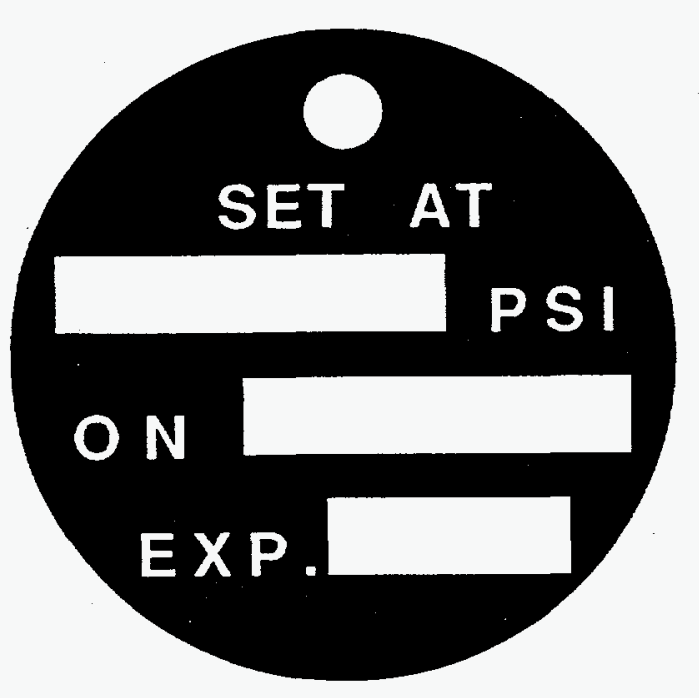

BACK

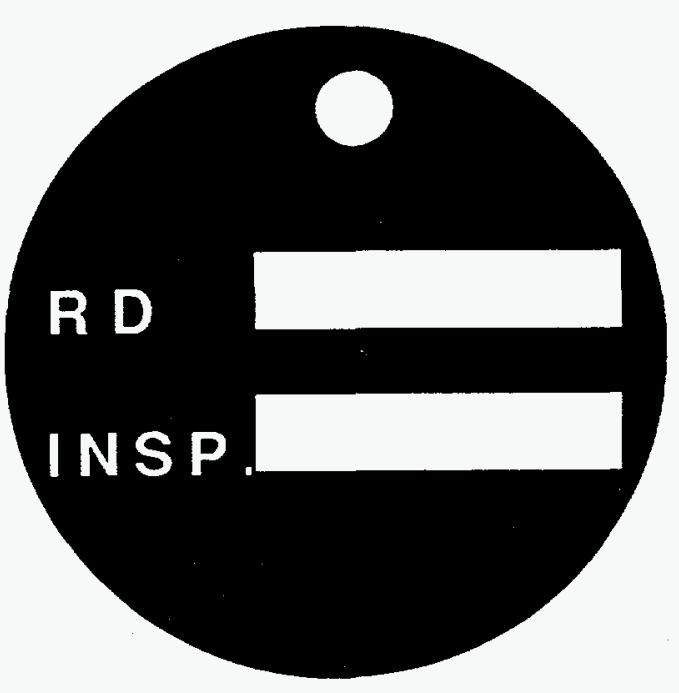


APPENDIX :

Sample page from Log Book 


\section{PRESSURE TEST LOG}

\begin{tabular}{|c|c|c|c|c|c|}
\hline TEST NUMBER & ORIG TEST & BLDG. & $\mathbf{R M} *$ & SAFETY NOTE NUMBER & ORIG INSPECTOR \\
\hline ME1631 & $2 / 5 / 91$ & 391 & 1314 & ENE86-927 & D. RODRIGUEZ \\
\hline ME1632 & $2 / 7 / 91$ & 131 & HYBY & ENW91-905 & T. ARNOLD \\
\hline ME1633 & $2 / 7 / 91$ & 131 & HYBY & ENW91-905 & T. ARNOLD \\
\hline ME1634 & $2 / 7 / 91$ & 131 & HYBY & ENW91-905 & T. ARNOLD \\
\hline ME1635 & $2 / 7 / 91$ & 131 & HYBY & ENW91-905 & T. ARNOLD \\
\hline ME1636 & $2 / 7 / 91$ & 131 & HYBY & ENW91-905 & T. ARNOLD \\
\hline ME1637 & $2 / 7 / 91$ & 131 & HYBY & ENW91-905 & T. ARNOLD \\
\hline ME1638 & $2 / 21 / 91$ & 298 & 141 & ENS87-922 & T. ROSS \\
\hline ME1639 & $2 / 27 / 91$ & 381 & 1532 & ENS87-922 & T. ROSS \\
\hline ME1640 & $3 / 6 / 91$ & 827 & CCELL & END90-915 & R. MARSHALL \\
\hline ME1641 & $3 / 11 / 91$ & 151 & BASE & ENN79-906 & R. CARNAHAN \\
\hline ME1642 & $3 / 11 / 91$ & 151 & BASE & ENN79-906 & R. CARNAHAN \\
\hline ME1643 & $3 / 11 / 91$ & 151 & BASE & ENN79-906 & R. CARNAHAN \\
\hline ME1644 & $3 / 11 / 91$ & 151 & BASE & ENN79-906 & R. CARNAHAN \\
\hline ME1645 & $3 / 11 / 91$ & 151 & BASE & ENN79-906 & R. CARNAHAN \\
\hline ME1646 & $3 / 11 / 91$ & 151 & BASE & ENN79-906 & R. CARNAHAN \\
\hline ME1647 & $3 / 11 / 91$ & 235 & 1226 & END79-907 & R. PARKER \\
\hline ME1648 & $3 / 14 / 91$ & 332 & 1370 & ENS87-922 & T. ROSS \\
\hline ME1649 & $3 / 24 / 91$ & 332 & 1370 & ENW91-903 & F. GREEN \\
\hline ME1650 & $3 / 22 / 91$ & 490 & 1415 & ENE87-950 & G. HAILEY \\
\hline ME1651 & $2 / 27 / 91$ & 490 & HYBY & ENE91-902 & B. KELLY \\
\hline ME1651A & $2 / 27 / 91$ & 490 & HYBY & ENE91-902 & B. KELLY \\
\hline ME1651B & $2 / 27 / 91$ & 490 & HYBY & ENE91-902 & B. KELLY \\
\hline ME1652 & $4 / 1 / 91$ & 332 & 1354 & ENW91-906 & D. GIRE \\
\hline
\end{tabular}




\section{APIENIDIX 9}

\section{Pressure Test/Inspection Record}

(Form LL 3586) 
Lawrence Livermore National Laboratory

Engineering Note ENS92-06

Appendix 9 Page 2

PRESSURE TEST/INSPECTION RECORD

Test No. NUMBER

Date: DATE

BASIC INFORMATION: Enter here and on original (or new) LLNL Pressure Tested label.

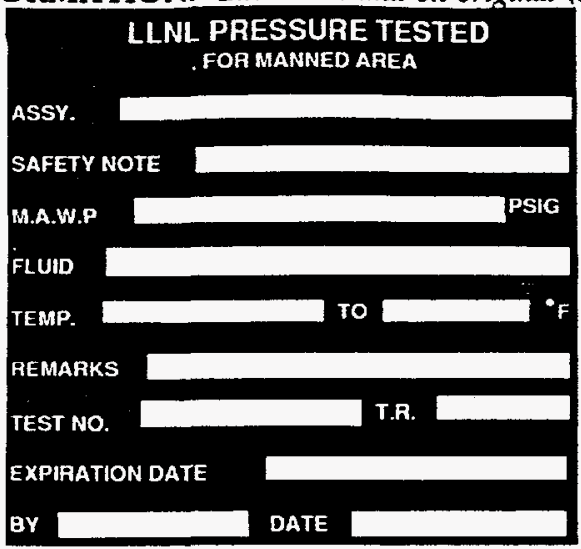

Location of vesed (or system): Bids. $\mathbf{R m}$.

Description:

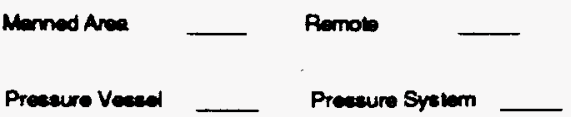

Preseure inspectore name and date of test or inspection

\section{TEST INFORMATION:}

1. Test Pressure.

PSIG.

2. Testing Fluid (oil, $\mathrm{He}$, etc.).

3. Test temperature ${ }^{\circ} \mathrm{C}$ $\circ$ F)

4. Test Report Number (H.P. Lab only).

5. Responsible Designer User Dept. User Payroll Acct.

6. Responsible User User Div.

7. Diameter measurements (for pressure vessel tests only) Location (marked) Before testing

After testing

Difference (+ or -$)$

INSPECTION INFORMATION:

Inspect the following and check $(\Omega$ appropriate column, explaining as required.

1. General appearance of system (or vessel)

2. Reilef devices are: a. Properly set (have them checked; reset)

b. Properiy sealed

c. Pointed in safe direction or safely vented

3. All fittings and vessel seals are leak tight

4. Replaced/added fittings, gauges, valves, (and piping") are properly rated

5. All system components are adequately secured

6. Valve packing nuts are tight, and locked (if locking type)

7. Oil is not apparent on or in" gas (especially oxygen) systems

8. The outside surface of the vessel shows no evidence of strain, damage, or corrosion

9. The inside surface of the vessel shows no evidence of strain

10. Lined vessel vent path is unobstructed: Check with helium

11. Vessel or system seals are leak-tight. Have replaced as required

12. The vessel or system is safe for continuing operation

13. Vessel or system was pressure tested within the last 6 years, or as required by the safety note. (If not, and certified for manned-anea operation, retest it and submit a Pressure Test Recond.)

\begin{tabular}{|c|c|c|}
\hline $\begin{array}{c}\text { Satio } \\
\text { factory }\end{array}$ & $\begin{array}{c}\text { Uncti- } \\
\text { factory }\end{array}$ & Remarks \\
\hline & & \\
\hline & & \\
\hline & & \\
\hline & & \\
\hline & & \\
\hline & & \\
\hline & & \\
\hline & & \\
\hline & & \\
\hline & & \\
\hline & & \\
\hline
\end{tabular}

- Consider assurance by the Responsible User as satisfactory verification 
Engineering Note ENS92-06

Appendix 10 Page 1

APPENDIX 10

LLNL Pressure Tested Label 


\section{LLNL PREssuRe tested FOR MANNED AREA}

ASSY.

SAFETY NOTE

M.A.W.P.

FLUID

T E M P.

REMARKS

TEST NO.

EXPIRATION DATE

B Y 


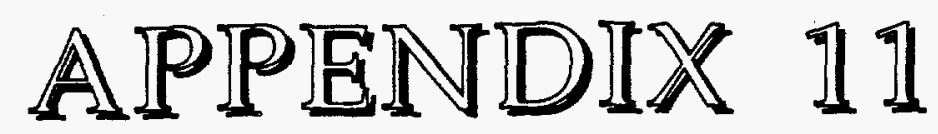

Sample Inspection/Retest Report 
Building: 131 M.E. Test Number: ME0931

Room: HIBY

Description: S/STEEL TUBING AND ONE MONEL TUBE AND Y BLOCK ASSEMBLY

Last Tested: 06/14/89

Last Inspected 6/14/89

Status: U

Test Report Number: 6892

Safety Note Number: ENW89-907

Test Interval: 0

Type of System: V

Manned or Remote: $M$

M.A.W.P.: 475

Fluid: INERT GAS

RD Number:

Designer: T. CHOW

Payroll Acct: 9772

User: J. LIETZKE Inspector: R. HAMPTON

Building: 131 M.E. Test Number: ME0939

Room: 2373

Description: SOLID STATE DEVICE FACILITY GAS SUPPLY SYSTEMS

Last Tested: $12 / 13 / 82$

Last Inspected 1/13/91

Safety Note Number: ENS82-904

Status: U

Test Report Number:

Manned or Remote: $M$

Test Interval: 1

Type of System: S

RD Number:

Designer: M. MAYR

Payroll Acct: 9785

User: D. CIARLO Inspector: M. TRAINI

Fluid: $\mathrm{O} 2$

Building: 131 M.E. Test Number: ME0939

Room: ND

Description: SOLID STATE DEVICE FACILITY FOR SUPPLY SYSTEM

Last Tested: $12 / 13 / 82$

Last Inspected 1/31/91

Safety Note Number: ENS82-904

Status: U

Test Report Number: 6892

Manned or Remote: $M$

M.A.W.P.: 100

Test Interval: 1

Type of System: S

RD Number:

Designer: M. MAYR

Payroll Acct: 9772

User: D. CIARLO Inspector: M. TRAINI

Fluid: SIH4+15\%N2 
APIENDIX 12

Stored-In-Place Record

(Form LL 6278) 
Lawrence Livermore National Laboratory PRESSURE TEST/INSPECTION RECORD
Test No. NUMBER

Date: DATE

BASIC INFORMATION: Enter here and on original (or new) LLNL Pressure Tested label.

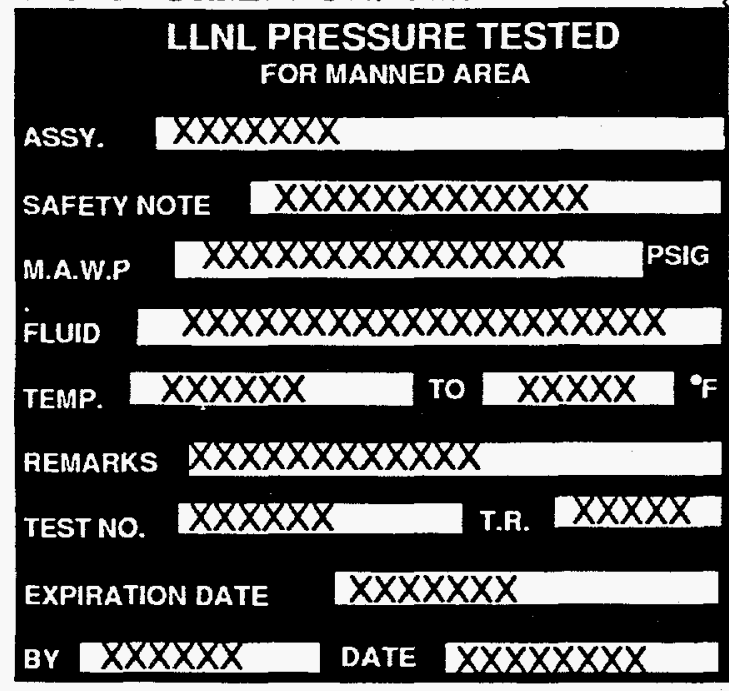

\section{COMMENTS:}

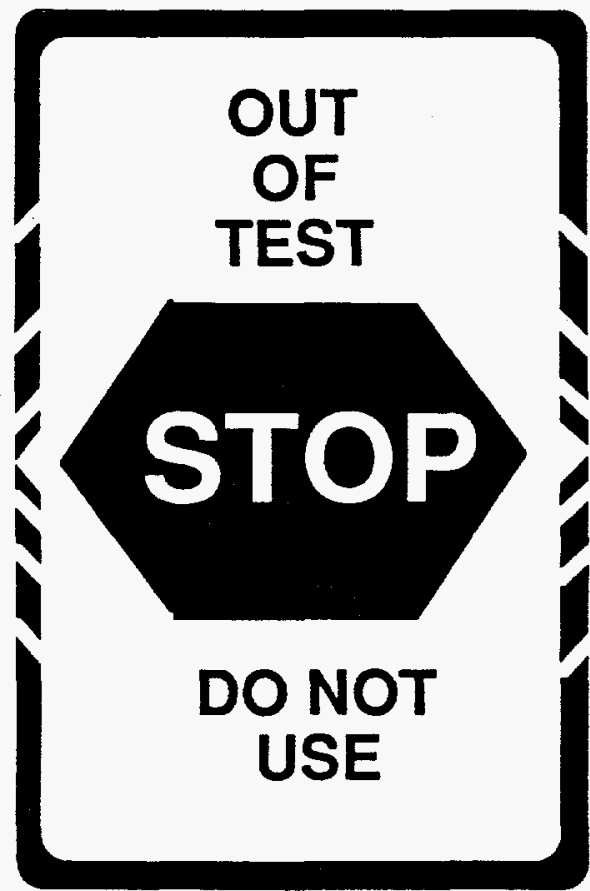

LL6278

Send this completed form to the LLNL Pressure Inspector, L-384
Location of vessel (or system): Bldg: Rm.

Description:

Manned Area $-\quad$ Remote
Pressure vessel $-\quad$ Pressure System - (Check applicable boxes)
$=$ Pressure Inspector's name and date of test or inspection.

Responsible User Please Read and Sign

As a person responsible for the safe operation of this equipment, I agree that before this equipment is put back into use, I will notify the pressure inspectors at Bldg. 343. I will arrange with them to have the system reinspected, tested, tagged and a new LLNL pressure tested label attached before re-use of the equipment. If I am transferred or leave the area, I will inform the next responsible user as to the requirements for reinstatement of this equipment.

This equipment is out of service and is considered stored in place as of

Signature of Responsible User

Building

Rm. Ext.

Date taken out of service 
A.PPENDIX 13

Group Controlled Items - Stock Catalog 


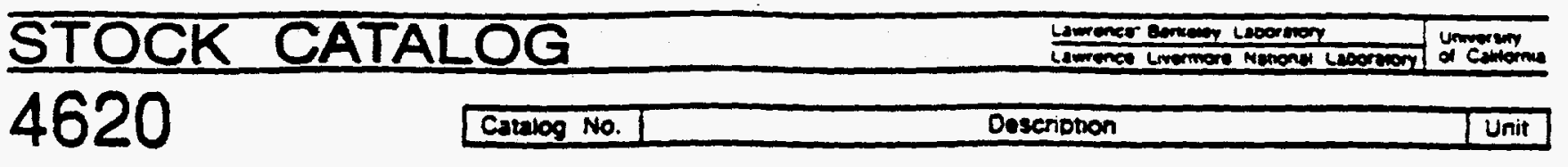

GROUP 46 HIOH PRESSURE COMPONENTS

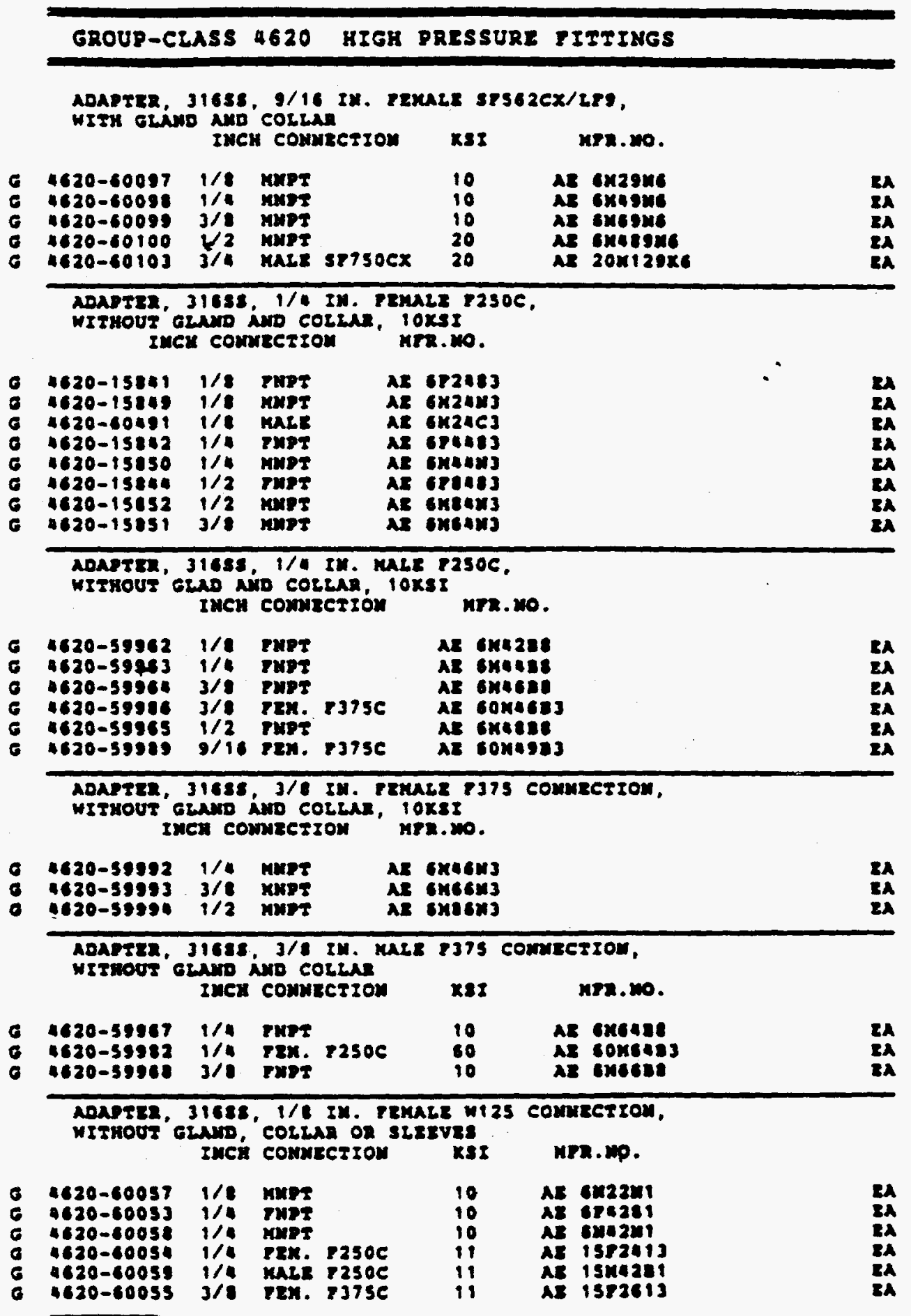


APPINDIX 14

\section{Pressure Safety Codes and Standards}




\section{PRESSURE SAFETY CODES AND STANDARDS}

- Federal OSHA

29 CFR 1910, "General Industry Standards"

29 CFR 1926, "Construction Standard"

49 CFR 173, "Transportation"

- National Fire Protection Association (NFPA)

- American National Standards Institute (ANSI)

- United States Department of Transportation (DOT)

- America Society of Mechanical Engineering (ASME)

- Compressed Gas Association (CGA)

- Local/State Codes

- DOE Order 5000.3A, "Occurrence Reporting"

- DOE Order 5480.4, "Environmental Safety and Health Protection Standard

- DOE Pressure Safety Guidelines Manual

- Lawrence Livermore National Laboratory Health and Safety Manual

- Design Safety Standards, Mechanical Engineering Department, Lawrence Livermore National Laboratory 